\title{
"I Teach the way I believe": EFL Teachers' Pedagogical Beliefs in Technology Integration and its Relationship to Students' Motivation and Engagement in the COVID 19 Pandemic Year
}

\author{
Russell D' Souza \\ Department of Education, Nirmala Institute of Education, India \\ https://orcid.org/0000-0002-1500-5686 \\ Jayashree Premkumar Shet \\ College of Science and Arts, An Nabhanya, Qassim University, Saudi Arabia \\ https://orcid.org/0000-0001-6943-9706 \\ Joel Alanya-Beltran \\ Universidad Tecnológica del Perú, Peru \\ https://orcid.org/0000-0002-8058-6229 \\ Korakod Tongkachok \\ Faculty of Law, Thaksin University, Thailand \\ https://orcid.org/0000-0002-2381-9161 \\ Geena Hipolito-Pingol \\ Pampanga State Agricultural University, Philippines \\ https:// orcid.org/0000-0002-1346-7553 \\ Mohamed Aboobucker Mohamed Sameem \\ South Eastern University of Sri Lanka, Sri Lanka \\ https://orcid.org/0000-0002-5164-5277
}

\begin{abstract}
This study aimed to investigate language teachers' pedagogical concepts and attitudes and the effect of these on students' motivation and engagement levels. Its results were based on a cross-sectional correlational research survey which was conducted online. The participants in the study were chosen at random from among 205 language teachers $(n=205)$ and 317 language students $(n=317)$ from various higher educational institutions in Asian countries. Results of the study of language teachers revealed that the respondents' pedagogical ideas and orientations were positive when it came to using technologybased teaching in their language classroom. Results of gender differences
\end{abstract}


indicated that female language teachers showed a firmer belief in studentcentered online language learning than their male counterparts. On the other hand, males are more likely than females to utilize technology in the language classroom, and their attitudes relating to it are more favorable than those of their female counterparts. The levels of language learning motivation and engagement among students were also investigated. The findings also showed a high level of language learning engagement among both male and female students. Furthermore, the test of relationship showed that the firmer the instructors' belief in the importance of student-centered teaching and the incorporation of technology in the language classroom, the more driven and engaged the students are in language learning. Students' motivation and involvement in online language learning are not related to their views about the significance of instructors in their life, which is contrary to what many people believe. When it comes to incorporating technology into language courses, there are several pedagogical assumptions that enable EFL teachers to do so effectively. More broadly stated, this study has implications for increasing language instructors' digital literacy to develop more motivating, productive, and engaging language courses for 21st-century learning to improve language students' digital literacy.

Keywords: teachers' pedagogical orientation; technology; language learning; online classrooms

\section{Introduction}

The effect of technological advancements on education has been extensively documented in the literature. In recent years, the use of technology in education as a teaching tool has gained popularity. Unfortunately, not all EFL instructors are using contemporary technology advances to improve learning in the classroom, which is a major problem (Ding et al., 2019, Martin et al., 2020). The views of the instructor are one of the most significant elements that influence variables such as the usage of technology. Pedagogical principles significantly affect teaching methods, and instructors would select an English learning style that best represents their own views and beliefs as a consequence of this effect (Chen \& Kent, 2020). EFL pedagogical views (whether official or informal) include a wide variety of topics, from the planning, implementation, and evaluation of a language program to the evaluation of instructional materials. Unlike a studentcentered belief, a teacher-centered belief is concerned with the knowledge and understanding of the instructor, while a student-centered belief is concerned with the participation and success of the students (Tondeur et al., 2017). According to a prior study, students prefer instructors who have a student-centered pedagogical perspective and utilize technology in their courses over instructors who have a teacher-centered pedagogical perspective and use technology in their courses (Lo \& Hew, 2020; Zhou \& Wei, 2018). An investigation of the relationship between instructors' pedagogical values and student learning interest when technology is utilized in the classroom has not been conducted, and none of the prior research has taken pedagogical values into consideration (Alley, 2019; Burke et al., 2018; Jeong, 2019; Yimaz, 2017). Consequently, in this present study the researchers investigated the pedagogical concepts followed by EFL teachers in more depth as well as their learning commitment to using technology. With 
respect to learner engagement, the researchers are particularly interested in identifying which elements of pedagogy have the most impact on students' participation.

\section{Teacher Pedagogical Belief}

The development of a belief system by an individual is indicative of the development of personal confidence. A belief system is defined as a mental representation that anticipates or indicates a reality or state of validity. As defined by Tondeur et al. (2017), conviction is the belief that a collection of ideas is true, while intelligence is characterized as empirical propositions or concepts. An individual's belief is usually regarded as accurate in the sense that it serves as a filter through which the individual's experience is filtered (Lo \& Hew, 2020). A pedagogical belief is one that may be implemented based on the teachers' confidence in teaching and knowledge of educational theory. Teachers' views are influenced by their past experiences, which serve as the basis for planned activity and classroom behavior in the classroom (Magulod Jr, 2017a, 2017b, 2017c). For the sake of this study, pedagogical beliefs may be defined as the assumptions maintained by EFL teachers while teaching in their classes (Chen \& Kent, 2020; Yilmaz, 2017). There are two types of beliefs held by teachers: the teacher-centered belief and the student-centered belief, both of which are discussed here. The behaviorist principles that underpin the teacher-centered worldview are often invoked (Alley, 2019; Burke et al., 2018). The results of the students' evaluations serve as proof of the effectiveness of the teachers' lessons. Students are being provided with information as though they are just receptacles for fact-checked material, which is incorrect (Lai et al., 2018). Their viewpoints are often regarded negatively, and teachers are charged with promoting students' meaning and interpretation of events they witness and experience in the classroom (Hinostroza et al., 2021). Thus, pedagogical beliefs represent the teaching methods used by ESL teachers in their classes as a response to the methodological ideas held by their students (Olelewe et al., 2021).

\section{The Role of Pedagogical Belief in Technology Integration}

Many online technological devices are intended to assist in the learning of foreign languages. Numerous elements of language learning have been shown to be improved via the use of technology, including increasing the desire to study English, extending vocabulary capacity, and applying other innovations that language teachers have not made use of to their maximum potential (Jaafar et al., 2021, Magulod Jr, 2017a, 2017b; Polat \& Harabatak, 2021). Technology in their classes is not adequately supported, and this is a major problem. According to recent research, teachers utilize technology in the classroom regardless of their pedagogical ideas or beliefs (Bouchey et al., 2021; Tai \& Chen, 2021; Abou-Khalil et al., 2021). As a result of its ability to filter everything that is good and helpful into the teacher's values, the technology significantly impacts education. According to the results of a study conducted by Polat and Karabatak (2021), teachers who have pedagogical attitudes that are focused on EFL showed lower levels of engagement while utilizing technology to educate in their courses. Teachers who place a strong focus on the pedagogical value of student-centered instruction have been shown to be more hesitant to utilize technology in lesson preparation (Wang et al., 2021). Student-centered values encourage teachers to 
utilize and integrate technology into their courses, which results in increased productivity in the classroom. Pedagogical belief-based instructors use instructional technology to assist students' development of higher-order thinking, increase learning, improve students' capacity to utilize knowledge and skills, and offer students a platform for practice and reflection (Akongoh, 2021; Machisi, 2021; Tadesse et al., 2021).

According to their preferences, language instructors may distinguish between teacher-centered and student-centered educational methods in the context of a community of teachers and students (Tadesse et al., 2021). A community environment has been created in order to better understand the teacher-centered and student-centered community environments in which EFL instructors work. In previous studies (Barrett et al., 2021; Divekar et al., 2021), the factors affecting technology incorporation in the EFL learning environment were teachers' pedagogical approaches based on skills and rules as well as their application clustered on skill-based, rule-based, and application; and possible implementations. In the case of foreign language instruction, the concept established by Johnson (2006) may be used. A skill-based activity could be described as one in which the instructor employs a digital timer and sound or phrase patterns on a regular basis, for example, since consistency and memory are important components of technology integration in the classroom. If a teacher provides reference books and dictionaries to students to aid them in increasing their vocabulary, this might be considered an example of rule-based education, as described above. The use of a function-based approach to participation by an instructor is referred to as a "task-based exercise"; however, this is not always the case (Karaseva et al., 2018).

\section{Learning Engagement, Performance, and Motivation}

The development of learning engagement is required in order to have active participation and motivation to learn as well as increasing students' learning performance (Bakker et al., 2012; Magulod Jr, 2018a, 2018b, 2018c; Magulod Jr et al., 2020, Wu et al., 2020). Making a full commitment to a certain position within the educational process means investing in learning. When it comes to student participation in classroom teaching and learning, both mental and physical attention are essential aspects to take into consideration (Koh et al., 2017; Mei et al., 2018). As a consequence, engagement should be defined as the active participation or participation of students in their learning in this context. Student performance, on the other hand, is assessed according to the majority of projections. Around $80 \%$ of English teachers, according to estimates, assess success only on the basis of production, rather than on the premise of making it possible for students to learn (Johnson, 2006; Kawinkoonlasate, 2019; Sadaf \& Johnson, 2017). The involvement of the school community has been shown to enhance overall student performance (Lai et al., 2017; Tsai et al., 2019). When students are present and actively engaged in the learning process, they will often have the chance to discover their own potential. In order to inspire students, teachers must spend a significant amount of time providing high-quality teaching to the students. It is anticipated that boosting student enthusiasm for studying 
will have a positive impact on learning outcomes and learning efficiency in the long run (Gong \& Lai, 2018, Tavakoli et al., 2019).

\section{Research Objectives}

Despite the fact that many studies evaluated student involvement in technologybased learning, the perspectives of instructors on pedagogy have not been thoroughly investigated. In general, this research aims to identify the pedagogical orientations of language instructors when it comes to integrating technology in the online classroom and the impact of this integration on students' motivation and engagement. To be more specific, it aspires to offer responses to the following objectives:

1. Identifying the pedagogical orientations of language teachers toward the use of technology-based teaching;

2. Determining the level of online language learning engagement among students;

3. Assessing the differences in the pedagogical styles of instructors when they are grouped according to their profile variables; and

4. Examining the relationship between teachers' pedagogical orientations toward integrating technology in the online language learning environment.

\section{Methodology}

To examine language teachers' pedagogical views on online learning as well as the relationship between student motivation and engagement in the online language classroom, a descriptive correlational survey technique was utilized in conjunction with an online language classroom. As a consequence, this investigation is similarly cross-sectional in nature. In this way, the relationship between the variables that were found throughout the study could be established, with the ultimate aim of producing an engaging language lesson online as the end result. According to Qaranta (2017), a descriptive correlational survey research design is a kind of study in which the investigators are interested in identifying the relationship between a number of variables. In the research, the participants comprised 205 randomly selected language teachers $(n=205)$ and 317 randomly selected language students $(n=1800)$. The sampling representations were taken from Asian universities, in particular those from the countries of India, Saudi Arabia, Thailand, Philippines and Sri Lanka. The researchers collaborated online to obtain data from the students in their respective universities. Proper coordination and constant communication among the participating authors were ensured. The researchers employed a technique known as systematic random sampling for their investigation. A written request was made to the universities' administration, seeking the official lists of teachers and students, which was promptly fulfilled. Using the free online Raosoft sampling calculator, the sample was computed with a 5\% margin of error, a 95\% confidence level, and a 50\% distribution rate. While this was happening, the systematic sampling technique was utilized to choose the research samples, with three being the random start number for instructor responses and five being the random start number for student responses. To begin with, the institution granted authorization for the study to be conducted in the first place, which addresses ethical issues. Before 
taking part in the research, both groups of participants provided their informed consent to participate.

Table 1: Participants' profile

\begin{tabular}{lcccc}
\hline & $\begin{array}{c}\text { Teacher } \\
\text { Respondents }\end{array}$ & $\begin{array}{c}\text { Percentage } \\
\text { Distribution }\end{array}$ & $\begin{array}{c}\text { Student } \\
\text { Respondents }\end{array}$ & $\begin{array}{c}\text { Percentage } \\
\text { Distribution }\end{array}$ \\
\hline Male & 110 & $35 \%$ & 89 & $43 \%$ \\
Female & 207 & $65 \%$ & 116 & $57 \%$ \\
\hline Total & $\mathbf{3 1 7}$ & $\mathbf{1 0 0} \%$ & $\mathbf{2 0 5}$ & $\mathbf{1 0 0 \%}$ \\
\hline
\end{tabular}

Male and female respondents are represented in Table 1, indicating that females outnumber males in terms of the percentage of respondents in the survey. The information and data privacy forms for the participants were distributed to each of them prior to the start of the study. Apart from that, the respondents' identities, confidentiality, and privacy were all monitored both before and after the data was accessible. To them, it was critical that they were completely aware of the research's only aim and that any information gathered about them was strictly confidential and intended only for the purposes of this study.

Both qualitative and quantitative research tools were utilized in this study, and they were split into two groups. A modified version of the survey tool created by Palak (2004) to evaluate teachers' pedagogical ideas and orientations in integrating technology in the online classroom is provided below (Table 2). This instrument was created in order to obtain teachers' opinions on the use of technology in the classroom. Teacher educational philosophy was divided into five categories: teacher preparation for computer use, confidence in using technology, computer integration in the classroom, and attitude toward computer utilization. Five dimensions were incorporated in the tool. A questionnaire developed by Saheb (2015) was utilized to gather information from the student responders; this was altered and adjusted to meet the needs of this study. It may be divided into three categories: intrinsic engagement and motivation, integrative involvement and motivation, and extrinsic involvement and motivation. Neither of the research instruments was utilized until it had been thoroughly pre-tested by the researcher with the help of industry experts before being used. In order to collect the information, a Google Survey form was created and utilized to conduct the survey online. Several weeks before the study's implementation, researchers contacted the respondents by phone and email, requesting them to answer the instruments that had been sent to their email account by the researcher. Several security measures were included in the survey, such as the need for respondents to enter their passwords before being able to access the survey results file. This was done in order to avoid the duplication of information on the Internet.

The researchers used the following data analysis methods in order to determine the variables that contributed to student performance: Frequency distributions and percentages were employed to evaluate respondents' attributes, while the mean, as well as the weighted mean and standard deviation, were used to quantify the variables' values. Inferential statistics such as T-test and ANOVA were used to ascertain the differences in the students' responses when grouped according to selected profile variables. The scale employed was 4.20-5.00: 
Always/Strongly agree; 3.40-4.19: Very often/Agree; 2.60-3.39: Sometimes/Undecided; 1.80-2.59: Rarely/ Disagree; and 1.79: Never/Strongly disagree. The Statistical Package for Social Science (SPSS) software version 20 was used.

\section{Results and Discussion}

3.1. Language teachers' pedagogical orientations on the use of technology-based teaching

Table 2 depicts the pedagogical orientations of language instructors in relation to the utilization of technology-based teaching methods. It is worth noting that the language teachers who answered the survey have a high degree of evaluation of their pedagogical orientation when it comes to the use of technology. Studentcentered belief $(x=3.46, s d=0.34)$ and teacher-centered belief $(x=3.50, s d=0.25)$ were high on their list of priorities in language instruction, according to their own assessment. This indicates that the respondents believe that a diversified approach of educational philosophies should be used in language instruction. They demonstrated a high level of computer preparation $(\mathrm{x}=3.44, \mathrm{sd}=0.23)$, as well as a high level of computer integration in their language lessons $(x=3.50, s d=0.21)$ in the same way, implying that they have a high level of competence in utilizing technology devices for their online classroom.

Furthermore, the language instructors had a very favorable attitude toward computer use $(x=3.43, \mathrm{sd}=0.31)$, which was consistent with the results of the study. Indeed, the teachers' pedagogical views and dispositions toward the use of technology-based instruction in their language classes are overwhelmingly favorable. This result of the research indicates that language instructors have a positive attitude about the use of technology in their classrooms. As a result, they are progressive in their outlook. Teachers' pedagogical perspectives on integrating technology into the classroom have been the subject of a number of studies in the past. As Chien and Wu (2020) observed, teachers' perceptions of classroom practice had a part in determining their technology priorities as well as the significance they gave to various technical barriers in their classrooms. Every teacher, regardless of the reason, claimed that they required sufficient technological tools in the classroom and that they were each affected differently by a lack of readily accessible technologies because each had their own ideas about what should be done in school, as pointed out by Tondeur (2020). Similar to the findings of Ifinedo et al. (2020), it has been shown that teachers' educational viewpoints are strongly linked to their use of technology in the classroom.

When it comes to integrating technology into the classroom, teachers' pedagogical views may both help and hinder their efforts. Beliefs about what children should be able to accomplish provide a barrier to the use of technology in the classroom. A lack of resources and equipment, as well as a lack of preparation, guidance, and assistance are just a few of the external hurdles to overcome. Some examples of second-order inhibitors include, among others, personal beliefs, technological perspectives, and the ability to adjust to new circumstances with ease. In earlier investigations, researchers looked at instructors' information literacy and instructional attitudes following the introduction of CCOVID 19 and found that 
they had improved. During the course of instruction, it was found that teachers' attitudes about information technology were related to their levels of IT literacy (Anderson \& Putman, 2020; Backfisch et al., 2021; Nelson \& Hawk, 2020; Top et al., 2021).

Table 2: Language teachers' pedagogical orientations

\begin{tabular}{|l|l|l|l|}
\hline Dimensions & Mean & SD & Interpretation \\
\hline Student-centered belief & 3.46 & 0.34 & High \\
\hline Teacher-centered belief & 3.50 & 0.25 & High \\
\hline $\begin{array}{l}\text { Teacher preparation for computer } 3.33 \\
\text { utilization }\end{array}$ & 0.23 & High \\
$\begin{array}{l}\text { Integration of computer in the } 3.50 \\
\text { classroom }\end{array}$ & 0.21 & High \\
\hline $\begin{array}{l}\text { Attitude towards computer } 3.43 \\
\text { utilization }\end{array}$ & 0.31 & High \\
\hline
\end{tabular}

Legend: 4.20-5.00: Very high/Strongly agree; 3.40-4.19: High/Agree; 2.60-3.39: Sometimes/Undecided; 1.80-2.59: Low/Disagree; 1.79: Very low/ Strongly disagree

\subsection{Students' level of online language learning engagement and motivation}

Table 3 provides a response to the research question about the level of engagement and motivation of students who were taking part in online language learning. The computed grand mean $(x=3.39)$ shows that the students' levels of involvement and motivation in online language learning are appropriate for their age and gender. Many of the learning tasks given by the teacher in their online classroom have been attributed with helping to achieve such a high level of student engagement. Each student's listening, speaking, reading, and writing assignments should be reviewed by the teacher in order to verify that they are actively engaged in the language learning process. According to the data in Table $3(x=3.41, \mathrm{sd}=0.14)$, students have a high level of intrinsic motivation and engagement in their language learning, which suggests that they are motivated and interested in their language learning. According to the findings of this study, students' motivation for online English courses is influenced by the teaching techniques and personalities of their online English teachers. Apart from that, the students showed a reasonable level of intrinsic motivation and engagement. The ability of students to be motivated to learn a new language is important in the process of learning a new language. Students' linguistic skills are developed in large part as a result of their drive, according to research on the role of motivation in language learning. The application of motivation is required for the development of language competence (Harvey, 2017; Lai \& Tai, 2021; Man et al., 2021; Schiller \& Dorner, 2021). In order for students to achieve their second or foreign language goals, teachers must play an important part in their success.

A variety of factors may affect one's level of motivation. The consequence is that students are more likely to enjoy the process of learning a new language when language teachers place emphasis on stimulation in their courses. The explanation gives learners a focal point of attention as well as a goal to strive towards in their learning. Therefore it plays an essential role in language learning. It is conceivable for students to have problems as a result of a lack of adequate motivation. If learners are not actively involved in the process of learning new abilities, it will 
be difficult for them to enhance their performance. It has been shown that paying attention to the value of language increases encouragement even when there is no intrinsic incentive present in the circumstance, according to Oga-Baldwin and Fryer (2020). Teachers should be aware of the many different methods by which students learn to be motivated in order to best assist them.

Table 3: Level of engagement of the students in online learning

\begin{tabular}{|l|l|l|l|}
\hline Dimensions & Mean & SD & Interpretation \\
\hline $\begin{array}{l}\text { Intrinsic engagement and motivation } \\
\text { (student-focused) }\end{array}$ & 3.37 & 0.23 & Fair \\
\hline $\begin{array}{l}\text { Extrinsic engagement and motivation } \\
\text { (teacher-focused) }\end{array}$ & 3.41 & 0.14 & High \\
\hline Grand Mean & 3.39 & & Undecided \\
\hline
\end{tabular}

Legend: 4.20-5.00: Very high/Strongly agree; 3.40-4.19: High/Agree; 2.60-3.39: Fair/Undecided; 1.80-2.59: Low/Disagree; 1.79: Very low/Strongly disagree

Researchers found that students in classes where their objectives were identical learned to proceed at their own pace, which made them feel more comfortable (Huang et al., 2020; Yang et al. 2020). Additionally, other significant findings from the test results showed that motivation has an effect on language ability (Chen \& Kent, 2020; Zainuddin et al., 2020). When it comes to learning a second language, the research of Hoi (2020) found that instrumental drive is more crucial than social motivation in most cases. Another finding of Hoi (2020) revealed that integrative encouragement is more important when learning English as a second language than when learning English as a first language. In the opinion of Reiterer et al. (2020), motivated learners exert more effort toward improving their language learning skills and, as a consequence, toward attaining their goals. According to the evidence now accessible to academics, learning a foreign language quickly may result in high levels of fluency in that language. Using this concept, the a pleasant and tranquil classroom environment is essential for motivating students and aiding their language acquisition. As Danesh and Shanazari (2020) point out, it is difficult to cultivate motivation in the setting of a challenging educational environment. Perhaps most importantly, language acquisition should take place in an environment that is both casual and informal, which is ideal for learning. According to Oga-Baldwin and Fryer (2020), there seems to be a connection between extrinsic incentives and language learning techniques.

\subsection{Difference in the pedagogical styles of instructors when grouped according to gender variable}

Table 4 presents the significant differences in the pedagogical styles of instructors when grouped according to gender variables. When the instructors were divided into groups based on their gender, the results revealed a statistically significant difference in their pedagogical methods and attitudes about technology integration. For example, student-centered belief $(\mathrm{p}$-value $=0.034)$, teacher preparation for computer utilization $(\mathrm{p}$-value $=0.012)$, integration of computers in the classroom $(\mathrm{p}$-value $=0.029)$, and attitude towards computer utilization $(\mathrm{p}$ value $=0.043$ ) are among the dimensions that showed differences, whereas there was no difference found for teachers' belief in teacher-centered online language teaching. This indicates that there is a statistically significant difference in the 
educational styles of the instructors when they are classified according to the gender variable.

According to the results of this study, female language teachers exhibited a firmer belief in student-centered online language learning than their male counterparts in the field of language instruction. This outcome is associated with the personality of female teachers, who are well-known for exhibiting maternal and caring conduct. According to the results of the previous study, it was concluded that women make better teachers than males, owing to their mothering experiences and caring attitude (Carrell et al., 2010: Carrington et al., 2008: ElEmadi et al., 2019; Slavich \& Zimbardo, 2012). That females are more interested in teaching and feel that it is a rewarding career for the vast majority of them is supported by research. Women are more vocal and emotional than men, and they are more ready to express their feelings about what they enjoy and hate. For a woman, the capacity to be multi-talented is the most admirable trait she has. Skills in facilitating student interaction, paying attention in class, keeping track of each student, and dealing with issues that occur among students are just a few examples. Nowadays, gendering in the classroom has grown to be more casual and informal as a result of the changing times.

In a similar vein, this study found that male language teachers had a higher level of preparation, integration, and positive attitude about using computers in their courses than their female counterparts. This suggests that male instructors are more likely than female instructors to show a greater willingness to accept technology. Female language teachers were shown to have lower levels of confidence in their capacity to utilize technology in language teaching, according to the results of the study. The ability of male teachers to teach STEM topics is much greater than the capacity of their female counterparts, according to previous studies (Jatiningsih et al., 2020; Sibgatullina et al., 2019; Woodcock, 2021; Xu \& Williams, 2019). Ibe et al. (2013) found a substantial difference between men's and women's perceptions of STEM ability and familiarity, which serves to underline their argument. They assessed 454 male and female instructors from 227 secondary schools in the study group. The study revealed that male teachers had a more in-depth understanding of the subject matter than their female colleagues.

Table 4: Difference in the pedagogical styles of instructors when grouped according to gender variable

\begin{tabular}{|l|l|l|l|}
\hline Dimensions & Gender & Mean & \multirow{2}{*}{ P-value } \\
\hline \multirow{2}{*}{ Student-centered belief } & Male & 3.48 & \multirow{2}{*}{$0.034^{*}$} \\
\cline { 2 - 3 } & Female & 4.34 & $0.374 \mathrm{~ns}$ \\
\hline Teacher-centered belief & Male & 3.45 & \\
\cline { 2 - 3 } & Female & 3.49 & \multirow{2}{*}{$0.012^{*}$} \\
\hline Teacher preparation for computer utilization & Male & 4.21 & \\
\cline { 2 - 3 } & Female & 3.52 & \multirow{2}{*}{$0.029^{*}$} \\
\hline Integration of computer in the classroom & Male & 4.18 & \\
\cline { 2 - 3 } & Female & 3.41 & $0.043^{*}$ \\
\hline Attitude towards computer utilization & Male & 4.32 & \\
\cline { 2 - 3 } & Female & 4.16 & \\
\end{tabular}

*= significant at 0.05 level ns= not significant at 0.05 level 


\subsection{The difference in the students' level of online language learning engagement and motivation}

Looking at the differences of the students' level of online language learning engagement and motivation when grouped according to gender as profile variable, the results show that there is no significant difference in the level of engagement of the students. It shows that the gender of the students is not a factor of difference in the online language learning engagement and motivation among the students. Hence, the null hypothesis of the study is accepted. This implies that both male and female students have high intrinsic and extrinsic language learning engagement and motivation.

Table 5: Difference in the students' level of online language learning engagement and motivation

\begin{tabular}{|l|l|l|l|}
\hline Dimensions & Gender & Mean & P-value \\
\hline Intrinsic engagement and motivation & Male & 3.45 & $0.34 \mathrm{~ns}$ \\
\cline { 2 - 3 } & Female & 3.54 & \\
\hline Extrinsic engagement and motivation & Male & 4.13 & $0.14 \mathrm{~ns}$ \\
\cline { 2 - 3 } & Female & 4.18 & \\
\cline { 2 - 3 } & & &
\end{tabular}

*= significant at 0.05 level ns= not significant at 0.05 level

In addition, both groups of students had a positive attitude about online language learning in the setting of this investigation. This research supports the findings of Abu-Radia (1997), who found that there was no statistically significant difference in the attitudes of male and female students toward language acquisition in the Canadian environment. As a result, this also runs counter to other research that has shown that female students are more motivated and engaged in language acquisition than male students because they are more naturally linguisticallyinclined than males (Yashima et al., 2017, Torres \& Alieto, 2019). Previous studies have found that gender is a significant factor in second language motivation (Baker \& MacIntyre, 2000; Namaziandost \& Akmak, 2020). They have also found that females are more motivated than males in language learning. In this study, we found that females were more motivated than males. Therefore,, the current findings of this research demonstrate that gender does not play a part in language learning motivation, as both male and female respondents are capable of understanding the importance of online learning in their language learning efforts. Furthermore, the study's findings revealed that both intrinsic and extrinsic motivation to learn a language via online mode are strongly linked to the appreciation of both male and female students regarding the importance of learning a language as part of their professional preparation. Previous selected studies also concur with this finding that online learning motivation and engagement showed no differences when gender is taken as a variable (Alqahtani, 2021; Halverson \& Graham, 2019; Richardson \& Newby, 2006).

\subsection{Relationship between teachers' pedagogical orientations in integrating technology in the online classroom and its effect on students' motivation and engagement}

Table 6 shows that there is a significant relationship between the teachers' pedagogical orientations in integrating technology in the online classroom to students' motivation and engagement. Hence, the study's null hypothesis stating 
no significant relationship between pedagogical orientation and student motivation is rejected. It can be seen that student-centered belief ( $\mathrm{r}$ value $=0.778$, $\mathrm{p}$-value $=0.043)$, teacher preparation for computer utilization $(\mathrm{r}$-value $=0.698, \mathrm{p}$ value $=0.012)$, integration of computer in the classroom $(r$ value $=0.723, p$ value $=$ 0.011 ), and attitude towards computer utilization) $\mathrm{r}$ value $=0.863$, $\mathrm{p}$ value $=0.023$ ) are positively related to the student's level of engagement. This suggests that the greater teachers' belief in utilizing student-centered teaching to integrate technology in the language classroom, the more the students are motivated and engaged in learning. In like manner, it was also revealed that teacher-centered belief ( $\mathrm{r}$ value $=-0.531, \mathrm{p}$ value $=0.032)$ is negatively correlated to students' motivation and engagement in online language learning. This signifies that teacher-directed learning, such as the use of one-way directed learning, is found to be unappealing to the motivating of the language students.

Table 6: Relationship between teachers' pedagogical orientations in integrating technology in the online classroom and its effect on students' motivation and engagement

\begin{tabular}{|l|l|l|}
\hline & $\begin{array}{l}\text { Students' motivation and engagement } \\
\text { on online learning (r value) }\end{array}$ & P value \\
\hline Student-centered belief & 0.778 & $0.043^{*}$ \\
\hline Teacher-centered belief & -0.531 & $0.032^{*}$ \\
\hline $\begin{array}{l}\text { Teacher preparation for } \\
\text { computer utilization }\end{array}$ & 0.698 & $0.012^{*}$ \\
\hline $\begin{array}{l}\text { Integration of computer } \\
\text { in the classroom }\end{array}$ & 0.723 & $0.011^{*}$ \\
\hline $\begin{array}{l}\text { Attitude towards } \\
\text { computer utilization }\end{array}$ & 0.863 & $0.023^{*}$ \\
$*=$ significant at 0.05 level ns= not significant at 0.05 level & \\
\hline
\end{tabular}

This implies that the greater the degree to which the instructor conformed to teacher-centered views, the lower the level of motivation and engagement felt by the students. The grounds for this finding are that when students are given the opportunity to explore and acquire language courses via the use of studentcentered teaching methods in online learning, the results are positive. This suggests that higher levels of motivation and engagement of students would also increase their academic performance. To be clear, instructors' views about the incorporation of technology into the classroom had a substantial impact on students' desire to study. It may be stated that when instructors have a favorable attitude towards using technology in the classroom, they are more likely to demonstrate a student-centered teaching style, which in turn has an impact on students' learning behavior. Since the students are provided with learning opportunities to learn at their own pace and develop their linguistic competence using the technologies that are common to their generation in online learning environments such as digital games, blogging, podcasting, Facebook, WhatsApp, Viber, and learning management networks, the teachers' language learning tasks in online learning are taken into consideration by the students. This research also indicates that language instructors should stick to student-centered language learning methods and strategies to ensure that students enjoy language learning 
activities and that students' language learning anxiety is reduced as shown in the findings.

The findings of this research corroborate with earlier findings that instructors' pedagogical views about technology integration affect students' desire to learn new skills (Chamorro \& Rey, 2013, Cheng et al., 2020, Cullen \& Greene, B2011, Fryer \& Bovee, H2016, Ottenbreit-Leftwich, et al., 2020). However, there is no widely accepted notion of principles that are important to the integration of teaching technology. Further research is required to validate this discovery in order to arrive at definitive conclusions. In order to examine this connection with views related to technology among language instructors on online learning, the current researchers have focused on their own perceptions and ideas, which limits the scope of this current study. Immersive technologies for learning are important, according to research, since they encourage students to participate more actively in their learning. For a pedagogical knowledge of what is important in comprehending student learning and teaching, it is necessary to be familiar with the various philosophies of learning and teaching that instructors have about technological advancements and applications. Teachers will be better equipped to fulfill their responsibilities as 21st-century facilitators if schools are encouraged to review teachers' attitudes and technology integration methods. As a result, teachers' digital literacy as well as their views on student-centered activities will aid in the development of language instructors' abilities.

\section{Conclusion}

To evaluate student involvement in technology-based learning as well as instructors' pedagogical perspectives, the current study used a cross-sectional correlational research survey to collect data. The participants in the aforementioned research were randomly selected from a pool of 205 language instructors $(n=205)$ and 317 language students $(n=1800, n=317)$ from higher educational institutions in Asia. The study's findings revealed that respondents had favorable pedagogical attitudes and orientations about the use of technologybased instruction in their language classes. A test of difference revealed that female instructors had stronger beliefs in student-centered online language instruction than their male colleagues, according to the results of the study.

The employment of technology in the language classroom, on the other hand, is more positively linked with male instructors. Students' levels of language learning motivation and engagement were examined, and the results revealed that male and female students had similar levels of language learning drive and engagement. The test of relationship also revealed that the more confidence the instructors have in the value of student-centered teaching in the integration of technology in the language classroom, the more motivated and involved the students are in the process of learning the language.

Furthermore, it was shown that students' motivation and engagement in online language learning are adversely associated with their teacher-centered beliefs, according to the findings. The rationale for this discovery is that when students are enabled to explore language courses via the use of student-centered teaching 
methods in online education, the results are positive. These are the pedagogical ideas that encourage EFL instructors to incorporate technology positively into their language classrooms in this regard. As a result, instructors must be able to review their beliefs regarding the use of technology in EFL classrooms and how it affects students' involvement and motivation in their language study.

\section{Recommendations, Implications, and Future Research Direction}

Based on the results, this concept may be implemented by other schools' administrations in order to enhance EFL instructors' pedagogical ideas and values regarding the use of technology as a method of learning and development. Technologies may be utilized to engage EFL learners in group discussions on language structures and ideas such as the various types in order to foster collaboration among them and encourage them to work together in order to engage students in learning experiences and ensure that learning objectives are achieved.

In terms of practical and administrative implications, the research has the following recommendations: First and foremost, school administrators must reconsider the pedagogical advantages of technology integration for their language instructors since school leadership has an effect on teachers' acceptance and implementation of innovation. Second, instructors should become more effective and efficient 21st-century language educators as a result of ongoing capacity development in the area of technological integration.

To conclude, the provision of adequate technology resources for teachers is required due to the language instruction support curriculum, particularly for female teachers who have demonstrated a lower level of attitude toward the use of technology integration in the language classroom than male educators. The findings of the study on the beneficial connection between instructors' pedagogical views and student involvement may be further confirmed via mixedmethod research in the future, which is one of the study's research directions. Furthermore, additional personal profile factors such as rank, age, and the teachers' degree of experience to technological tools may be included for future studies in a similar way. It is necessary to do further research on the students' academic performance in order to determine their degree of achievement. It is possible to undertake research on the actual link between their exposure to teaching methods and the beliefs of the instructors. Furthermore, the use of real experimental study design and structural equation modeling (SEM) regarding the issue of inquiry linked to this may allow for more accurate conclusions about the results of the problem of inquiry.

\section{References}

Abou-Khalil, V., Helou, S., Khalifé, E., Chen, M. A., Majumdar, R., \& Ogata, H. (2021). Emergency online learning in low-resource settings: Effective student engagement $\quad$ strategies. Education $\quad$ Sciences, 11(1), 24 https:// doi.org/10.3390/educsci11010024

Akongoh, R. N. (2021). Teacher-based assessment of speaking in Cameroonian secondary schools: The impact of teacher training. Journal of English Language Teaching and 
Applied Linguistics, 3(2), 01-11. https://alkindipublisher.com/index.php/jeltal/article/view/1316

Alley, K. M. (2019). Fostering middle school students' autonomy to support motivation and engagement. Middle School Journal, 50(3), 5-14. https://doi.org/10.1080/00940771.2019.1603801

Alqahtani, K. M. (2021). The role of online student engagement on students' academic achievement (Doctoral dissertation, University of Kansas). https:// www.proquest.com/openview/2b3cd9f7f3914cb681705f99d7ccc9bc/1? pq-origsite $=$ gscholar $\& \mathrm{cbl}=18750 \&$ diss $=y$

Anderson, S. E., \& Putman, R. S. (2020). Special education teachers' experience, confidence, beliefs, and knowledge about integrating technology. Journal of Special Education Technology, 35(1), 37-50. https://doi.org/10.1177/0162643419836409

Backfisch, I., Lachner, A., Stürmer, K., \& Scheiter, K. (2021). Variability of teachers' technology integration in the classroom: A matter of utility! Computers $\mathcal{E}$ Education, 166, 104159. https://doi.org/10.1016/j.compedu.2021.104159

Baker, S. C., \& MacIntyre, P. D. (2000). The role of gender and immersion in communication and second language orientations. Language learning, 50(2), 311341.

Bakker, A. B., Demerouti, E., \& Lieke, L. (2012). Work engagement, performance, and active learning: The role of conscientiousness. Journal of Vocational Behavior, 80(2), 555-564. https://doi.org/10.1016/j.jvb.2011.08.008

Barrett, N. E., Liu, G. Z., \& Wang, H. C. (2021). Student perceptions of a mobile learning application for English oral presentations: The case of EOPA. Computer Assisted Language Learning, 1-26. https:/ / doi.org/10.1080/09588221.2021.1881975

Bouchey, B., Castek, J., \& Thygeson, J. (2021). Multimodal learning. Innovative Learning Environments in STEM Higher Education: Opportunities, Challenges, and Looking Forward, 35-54. https://library.oapen.org/handle/20.500.12657/47325

Burke, P. F., Schuck, S., Aubusson, P., Kearney, M., \& Frischknecht, B. (2018). Exploring teacher pedagogy, stages of concern and accessibility as determinants of technology adoption. Technology, Pedagogy and Education, 27(2), 149-163. https://doi.org/10.1080/1475939X.2017.1387602

Carrell, S. E., Page, M. E., \& West, J. E. (2010). Sex and science: How professor gender perpetuates the gender gap. The Quarterly Journal of Economics, 125(3), 1101-1144. https:// doi.org/10.1162/qjec.2010.125.3.1101

Carrington, B., Tymms, P., \& Merrell, C. (2008). Role models, school improvement and the 'gender gap' - do men bring out the best in boys and women the best in girls? British Educational Research Journal, 34(3), 315-327. https:// doi.org/10.1080/01411920701532202

Chen, J. C., \& Kent, S. (2020). Task engagement, learner motivation and avatar identities of struggling English language learners in the 3D virtual world. System, 88, 102168. https:// doi.org/10.1016/j.system.2019.102168

Chen, W., Tan, J. S., \& Pi, Z. (2021). The spiral model of collaborative knowledge improvement: An exploratory study of a networked collaborative classroom. International Journal of Computer-Supported Collaborative Learning, 1-29. https://link.springer.com/article/10.1007/s11412-021-09338-6

Chien, S. P., \& Wu, H. K. (2020). Examining influences of science teachers' practices and beliefs about technology-based assessment on students' performances: A hierarchical linear modeling approach. Computers $\mathcal{E}$ Education, 157, 103986. https://doi.org/10.1016/j.compedu.2020.103986 
Danesh, J., \& Shahnaazari, M. (2020). A structural relationship model for resilience, L2 learning motivation, and L2 proficiency at different proficiency levels. Learning and Motivation, 72, 101636. https:// doi.org/10.1016/j.lmot.2020.101636

Ding, A. C. E., Ottenbreit-Leftwich, A., Lu, Y. H., \& Glazewski, K. (2019). EFL teachers' pedagogical beliefs and practices with regard to using technology. Journal of Digital Learning in Teacher Education, 35(1), 20-39. https://doi.org/10.1080/21532974.2018.1537816

Divekar, R. R., Drozdal, J., Chabot, S., Zhou, Y., Su, H., Chen, Y., ... \& Braasch, J. (2021). Foreign language acquisition via artificial intelligence and extended reality: Design and evaluation. Computer Assisted Language Learning, 1-29. https://doi.org/10.17762/turcomat.v12i10.5268

El-Emadi, A. A., Said, Z., \& Friesen, H. L. (2019). Teaching style differences between male and female science teachers in qatari schools: Possible impact on student achievement. EURASIA Journal of Mathematics, Science and Technology Education, 15(12), em1800. https:// doi.org/10.29333/ejmste/109236

Gong, Y., \& Lai, C. (2018). Technology integration into the language classroom: Developmental trajectory of beginning teachers. Frontiers of Education in China, 13(1), 1-27. https://link.springer.com/article/10.1007\%2Fs11516-0180001-5

Halverson, L. R., \& Graham, C. R. (2019). Learner engagement in blended learning environments: A conceptual framework. Online Learning, 23(2), 145-178. https://eric.ed.gov/?id=EJ1218398

Harvey, L. (2017). Language learning motivation as ideological becoming. System, 65, 6977. https://doi.org/10.1016/j.system.2016.12.009

Hinostroza, J. E., Ibieta, A., \& Labbé, C. (2021). Using information problem-solving activities to teach: An exploratory study designed to improve teacher competencies related to internet use in the classroom. Technology, Pedagogy and Education, 1-21. https://doi.org/10.1080/1475939X.2021.1883105

Hoi, V. N. (2020). Understanding higher education learners' acceptance and use of mobile devices for language learning: A Rasch-based path modeling approach. Computers \& Education, 146, 103761. https:// doi.org/10.1016/j.compedu.2019.103761

Huang, S. Y., Kuo, Y. H., \& Chen, H. C. (2020). Applying digital escape rooms infused with science teaching in elementary school: Learning performance, learning motivation, and problem-solving ability. Thinking Skills and Creativity, 37, 100681. https:// doi.org/10.1016/j.tsc.2020.100681

Ibe, J. O., Adah, S. A., \& Ihejiamaizu, C. C. (2013). Assessment of secondary school chemistry teachers' quality through identification and use of laboratory apparatus in Cross River State, Nigeria. Assessment, 4(5).

Ifinedo, E., Rikala, J., \& Hämäläinen, T. (2020). Factors affecting Nigerian teacher educators' technology integration: Considering characteristics, knowledge constructs, ICT practices and beliefs. Computers $\mathcal{E}$ Education, 146, 103760. https://doi.org/10.1016/j.compedu.2019.103760

Jaafar, I., Statti, A., Torres, K. M., \& Pedersen, J. M. (2021). Technology integration and the teacher-student relationship. In D. Kloridou, E. Doukanari \& N. Eteokleous. Fostering meaningful learning experiences through student engagement (pp. 196-213). IGI Global.

Jatiningsih, O., \& Sari, M. M. K. (2020, March). Gender and education: Preparing teacher candidates of Civics to build egalitarian society in industry 4.0 era. In Proceedings of the 2nd Annual Civic Education Conference (ACEC 2019) (pp. 227-232). Atlantis Press. 
Jeong, K. O. (2019). Online collaborative language learning for enhancing learner motivation and classroom engagement. International Journal of Contents, 15(4), 8996. https://www.koreascience.or.kr/article/JAKO201900937426560.page

Johnson, K. E. (2006). The sociocultural turn and its challenges for second language teacher education. TESOL Quarterly, 40(1), 235-257. https://doi.org/10.2307/40264518

Karaseva, A., Pruulmann-Vengerfeldt, P., \&Siibak, A. (2018). Relationships between inservice teacher achievement motivation and use of educational technology: Case study with Latvian and Estonian teachers. Technology, Pedagogy and Education, 27(1), 33-47. https://doi.org/10.1080/1475939X.2017.1339633

Kawinkoonlasate, P. (2019). Integration in flipped classroom technology approach to develop English language skills of Thai EFL learners. English Language Teaching, 12(11), 23-34. https:/ / eric.ed.gov/?id=EJ1232443

Koh, J. H. L., Chai, C. S., \& Lim, W. Y. (2017). Teacher professional development for TPACK-21CL: Effects on teacher ICT integration and student outcomes. Journal of Educational Computing Research, 55(2), 172-196. https://doi.org/10.1177/0735633116656848

Lai, C., \& Tai, C. P. (2021). Types of social media activities and Hong Kong South and Southeast Asians Youth's Chinese language learning motivation. System, 97, 102432. https://doi.org/10.1016/j.system.2020.102432

Lai, C., Hu, X., \& Lyu, B. (2018). Understanding the nature of learners' out-of-class language learning experience with technology. Computer-Assisted Language Learning, 31(1-2), 114-143. https://doi.org/10.1080/09588221.2017.1391293

Lai, C., Li, X., \& Wang, Q. (2017). Students' perceptions of teacher impact on their selfdirected language learning with technology beyond the classroom: Cases of Hong Kong and US. Educational Technology Research and Development, 65(4), 1105-1133. https://link.springer.com/article/10.1007/s11423-017-9523-4

Lo, C. K., \& Hew, K. F. (2020). A comparison of flipped learning with gamification, traditional learning, and online independent study: The effects on students' mathematics achievement and cognitive engagement. Interactive Learning Environments, 28(4), 464-481. https://doi.org/10.1080/10494820.2018.1541910

Machisi, E. (2021). Grade 11 students' reflections on their Euclidean geometry learning experiences. EURASIA Journal of Mathematics, Science and Technology Education, 17(2), em1938. https://www.ejmste.com/article/grade-11-studentsreflections-on-their-euclidean-geometry-learning-experiences-9672

Magulod Jr, G. C. (2017a). Educational philosophies adhered by Filipino preservice teachers: Basis for proposing initiatives for 21st century teacher education preparation program. Asia Pacific Journal of Multidisciplinary Research, 5(1), 185192.

Magulod Jr, G. C. (2017b). Personal epistemologies and teaching Styles of Filipino preservice elementary teachers: Implications to teacher education preparation program. Asia Pacific Journal of Multidisciplinary Research, 5(1), 31-40.

Magulod Jr, G. C. (2017c). Factors of school effectiveness and performance of selected public and private elementary schools: implications on educational planning in the Philippines. Asia Pacific Journal of Multidisciplinary Research, 5(1), 73-83.

Magulod Jr, G. C. (2018a). Cognitive and attitudinal effects of movie poster making method in college classroom. Journal of Educational and Human Resource Development, 6, 42-58.

Magulod Jr, G. C. (2018b). Innovative learning tasks in enhancing the literary appreciation skills of students. SAGE Open, 8(4), 2158244018820382. https://doi.org/10.1177/2158244018820382 
Magulod Jr, G. C. (2018c). Use of innovative prewriting techniques in enhancing the writing performance and attitude of second year information technology students. Asia Pacific Journal of Multidisciplinary Research, 6(2), 1-9.

Magulod Jr, G. C., Capulso, L. B., Tabiolo, C. D. L., Luza, M. N., \& Ramada, M. G. C. (2020). Use of technology-based tools in ensuring quality of publishable journal articles. International Journal of Learning \& Teaching Education Research, 19(11), 145162. https://doi.org/10.26803/ijlter.19.11.9

Man, C. F., Sharif, S., May, A. L. J., Talin, R., \& Singh, S. S. B. (2021). The effects of dramabased activities as a language learning tool on learners' motivation in non-Malaymedium national schools in Malaysia. Indonesian Journal of Applied Linguistics, 10(3). https:// ejournal.upi.edu/index.php/IJAL/article/view/31742

Martin, A. J., Mansour, M., \& Malmberg, L. E. (2020). What factors influence students' realtime motivation and engagement? An experience sampling study of high school students using mobile technology. Educational Psychology, 40(9), 1113-1135. https:// doi.org/10.1080/01443410.2018.1545997

Mei, B., Brown, G. T., \& Teo, T. (2018). Toward an understanding of preservice English as a foreign language teachers' acceptance of computer-assisted language learning 2.0 in the People's Republic of China. Journal of Educational Computing Research, 56(1), 74-104. https://doi.org/10.1177/0735633117700144

Namaziandost, E., \& Çakmak, F. (2020). An account of EFL learners' self-efficacy and gender in the Flipped Classroom Model. Education and Information Technologies, 115.

Nelson, M. J., \& Hawk, N. A. (2020). The impact of field experiences on prospective preservice teachers' technology integration beliefs and intentions. Teaching and Teacher Education, 89, 103006. https:/ / doi.org/10.1016/j.tate.2019.103006

Oga-Baldwin, W. Q., \& Fryer, L. K. (2020). Profiles of language learning motivation: Are new and own languages different?. Learning and Individual Differences, 79, 101852. https://doi.org/10.1016/j.lindif.2020.101852

Olelewe, C. J., Doherty, F. V., Orji, C. T., \& Aneyo, I. (2021). Effects of innovative pedagogy integration in electrical installation and maintenance works in Enugu and Lagos states technical colleges. The International Journal of Electrical Engineering $\mathcal{E}$ Education, 0020720921997051.

Palak, D. (2004). Teachers' beliefs in relation to their instructional technology practices. https://www.proquest.com/openview/63a944ddb0551a4747cea945564ee6425/1? pq-origsite $=$ gscholar $\& \mathrm{cbl}=18750 \&$ diss $=\mathrm{y}$

Polat, H., \& Karabatak, S. (2021). Effect of flipped classroom model on academic achievement, academic satisfaction and general belongingness. Learning Environments Research, 1-24. https://link.springer.com/article/10.1007/s10984021-09355-0

Reiterer, S. M., Kogan, V., Seither-Preisler, A., \& Pesek, G. (2020). Foreign language learning motivation: Phonetic chill or Latin lover effect? Does sound structure or social stereotyping drive FLL?. In K.D. Federmeier \& H.-W. Huang (Eds.). Psychology of Learning and Motivation, 72, pp. 165-205. Academic Press. https://doi.org/10.1016/bs.plm.2020.02.003

Richardson, J. C., \& Newby, T. (2006). The role of students' cognitive engagement in online learning. American Journal of Distance Education, 20(1), 23-37. https://doi.org/10.1207/s15389286ajde2001_3

Sadaf, A., \& Johnson, B. L. (2017). Teachers' beliefs about integrating digital literacy into classroom practice: An investigation based on the theory of planned behavior. Journal of Digital Learning in Teacher Education,33(4), 129-137. https:// doi.org/10.1080/21532974.2017.1347534 
Saheb, V. (2015). Motivation in English as a foreign language learning: A study of motivation toward English language learning in Stockholm's upper secondary schools for adults (KOMVUX). https://www.divaportal.org/smash/record.jsf?pid=diva2\%3A782288\&dswid=8895

Schiller, E., \& Dorner, H. (2021). Factors influencing senior learners' language learning motivation. A Hungarian perspective. Journal of Adult Learning, Knowledge and Innovation. https://akjournals.com/view/journals/2059/aop/article-10.15562059.2020.00003/article-10.1556-2059.2020.00003.xml

Sibgatullina, T. V., Utemov, V. V., Galushkin, A. A., \& Zaitseva, N. A. (2019). Age heterogeneity of STEM educators. EURASIA Journal of Mathematics, Science and Technology Education, 15(7), em1730. https://www.ejmste.com/article/ageheterogeneity-of-stem-educators-7683

Slavich, G. M., \& Zimbardo, P. G. (2012). Transformational teaching: Theoretical underpinnings, basic principles, and core methods. Educational Psychology Review, 24(4), 569-608. https://link.springer.com/article/10.1007/s10648-0129199-6?null

Tadesse, A., Walter, A., \& Mitchell-Kernan, C. (2021). Integrating educational technology in East Africa: One size does not fit all. Monitoring of Public Opinion: Economic and Social Changes Journal (Public Opinion Monitoring), (1). https://cyberleninka.ru/article/n/integrating-educational-technology-in-eastafrica-one-size-does-not-fit-all

Tai, T. Y., \& Chen, H. H. J. (2021). The impact of immersive virtual reality on EFL learners' listening comprehension. Journal of Educational Computing Research, 0735633121994291. https:// doi.org/10.1177/0735633121994291

Tavakoli, H., Lotfi, A. R., Biria, R., \& Wang, S. (2019). Effects of CALL-mediated TBLT on motivation for L2 reading. Cogent Education, 6(1), 1580916. https://doi.org/10.1080/2331186X.2019.1580916

Tondeur, J. (2020). Teachers' pedagogical beliefs and technology use. In M. Peters. Encyclopedia of Teacher Education. Springer. https:// doi. org/10.1007/978-981-131179-6_111-1.

Tondeur, J., Van Braak, J., Ertmer, P. A., \& Ottenbreit-Leftwich, A. (2017). Understanding the relationship between teachers' pedagogical beliefs and technology use in education: A systematic review of qualitative evidence. Educational Technology Research and Development, 65(3), 555-575. https://link.springer.com/article/10.1007/s11423-016-9481-2

Top, E., Baser, D., Akkus, R., Akayoglu, S., \& Gurer, M. D. (2021). Secondary school teachers' preferences in the process of individual technology mentoring. Computers \& Education, 160, 104030.

Torres, J. M., \& Alieto, E. O. (2019). Acceptability of Philippine English Grammatical and Lexical Items among Pre-Service Teachers. Online Submission, 21, 158-181.

Tsai, M. C., Shen, P. D., Chen, W. Y., Hsu, L. C., \& Tsai, C. W. (2019). Exploring the effects of web-mediated activity-based learning and meaningful learning on improving students' learning effects, learning engagement, and academic motivation. Universal Access in the Information Society, 1-16. https://link.springer.com/article/10.1007/s10209-019-00690-x

Wang, Z., Pang, H., Zhou, J., Ma, Y., \& Wang, Z. (2021). "What if... it never ends?": Examining challenges in primary teachers' experience during the wholly online teaching. The Journal of Educational Research, 1-24. https://doi.org/10.1080/00220671.2021.1884823 
Washington, J. E., Shahrokni, S. A., Abobaker, R., \& Borysenko, N. (2021). “It's a chance to make mistakes": Processes and outcomes of coding in 2nd grade classrooms. Computers \& Education, 104173.

Woodcock, S. (2021). Teachers' beliefs in inclusive education and the attributional responses toward students with and without specific learning difficulties. Dyslexia, 27(1), 110-125. https://doi.org/10.1002/dys.1651

Wu, H., Li, S., Zheng, J., \& Guo, J. (2020). Medical students' motivation and academic performance: The mediating roles of self-efficacy and learning engagement. Medical Education $\quad$ Online, 25(1), 1742964. https://doi.org/10.1080/10872981.2020.1742964

Wu, J. F., \& Ching, G. (2020, October). A study on the elementary school teachers' information technology literacy and teaching beliefs in Taiwan. In Proceedings of the SITE Interactive Conference (pp. 323-329). Association for the Advancement of Computing in Education (AACE).

Xu, M., \& Williams, P. J. (2019). Technology teachers' attitude towards technology: An investigation of Chinese high school general technology teachers. PATT 37, 445. https://research.edgehill.ac.uk/ws/portalfiles/portal/20775897/PATT_37_Mal ta2019_Proceedings.pdf\#page $=445$

Yang, Q. F., Chang, S. C., Hwang, G. J., \& Zou, D. (2020). Balancing cognitive complexity and gaming level: Effects of a cognitive complexity-based competition game on EFL students' English vocabulary learning performance, anxiety and behaviors. Computers $\mathcal{E} \quad$ Education, 148, 103808. https:// doi.org/10.1016/j.compedu.2020.103808

Yashima, T., Nishida, R., \& Mizumoto, A. (2017). Influence of learner beliefs and gender on the motivating power of L2 selves. The Modern Language Journal, 101(4), 691711.

Yilmaz, R. (2017). Exploring the role of e-learning readiness on student satisfaction and motivation in flipped classroom. Computers in Human Behavior, 70, 251-260. https://doi.org/10.1016/j.chb.2016.12.085

Zainuddin, Z., Chu, S. K. W., Shujahat, M., \& Perera, C. J. (2020). The impact of gamification on learning and instruction: A systematic review of empirical evidence. Educational Research $\quad 100326$. https://doi.org/10.1016/j.edurev.2020.100326

Zhou, Y., \& Wei, M. (2018). Strategies in technology-enhanced language learning. Studies in Second Language Learning and Teaching, 8(2), 471-495.

https:/ / www.ceeol.com/search/article-detail?id=675397 